ENTREPRENEURSHIP AND SUSTAINABILITY ISSUES

ISSN 2345-0282 (online) http://jssidoi.org/jesi/ 2020 Volume 8 Number 2 (December) http://doi.org/10.9770/jesi.2020.8.2(4)

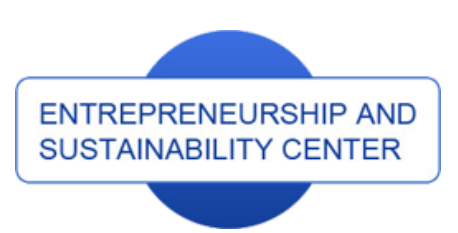

Publisher

http://jssidoi.org/esc/home

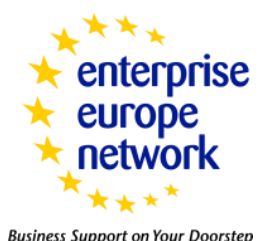

Business Support on Your Doorstep
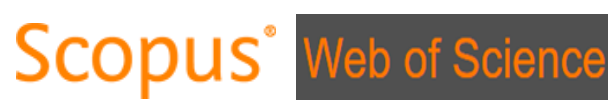

\title{
SUSTAINABLE MANAGEMENT OF FRESHWATER SWAMP FOREST AS AN ECOTOURISM DESTINATION IN INDONESIA: A SYSTEM DYNAMICS MODELING*
}

\author{
Sjaifuddin Sjaifuddin \\ Department of Science Education, Universitas Sultan Ageng Tirtayasa \\ Jl. Ciwaru Raya No.25, Cipare, Kec. Serang, Kota Serang, Banten 42117, Indonesia \\ E-mail: sjaifuddin@untirta.ac.id (corresponding author)
}

Received 15 May 2020; accepted 11 August 2020; published 30 December 2020

\begin{abstract}
As a freshwater swamp forest that still remains in Java, the existence of Rawa Danau as an ecotourism destination is important to be explored, because its utilization is not yet based on sustainable management principles. For this reason, a system dynamics modeling was then made that integrates various factors in the biophysical, social, and economic dimensions to obtain the best alternative for managing the future ecotourism destinations. Management alternatives are designed in three scenarios: deep ecotourism oriented to very strong/strong sustainability; shallow ecotourism oriented to weak sustainability; and mass tourism oriented to very weak sustainability. The results showed that deep ecotourism was the most suitable scenario to be implemented. Through this scenario, the control of several parameters that were successfully carried out during the 10 years of the simulation are as follows: 1) restrain the growth rate of tourist numbers so as not to burden the environment; 2) reforesting almost all forest land converted so that the restoration of forest functions goes well; 3 ) increase local community income so that the community gets adequate economic benefits; 4) increase environmental investment so that stakeholders benefit economically, ecologically, and socially in an integrated manner; 5) maintaining biodiversity at a high level; 6) maintain swamp water reserves at a very good level; 7) reduce the volume of solid waste so that it does not burden the environment.
\end{abstract}

Keywords: sustainable management; freshwater swamp forest; ecotourism destination; system dynamics modeling; Rawa Danau

Reference to this paper should be made as follows: Sjaifuddin, S. 2020. Sustainable management of freshwater swamp forest as an ecotourism destination in Indonesia: a system dynamics modeling. Entrepreneurship and Sustainability Issues, 8(2), 64-85. http://doi.org/10.9770/jesi.2020.8.2(4)

JEL Classifications: Q570, Q580

\footnotetext{
* The author would like to thank Universitas Sultan Ageng Tirtayasa, Indonesia for funding this research
} 


\section{ENTREPRENEURSHIP AND SUSTAINABILITY ISSUES}

ISSN 2345-0282 (online) http://jssidoi.org/jesi/

2020 Volume 8 Number 2 (December)

http://doi.org/10.9770/jesi.2020.8.2(4)

\section{Introduction}

In the last few decades, tourism has developed into one of the fastest growing industry sectors in the world. Globally, in 2020, it is estimated that the number of tourists will grow 3\% to 4\% (UNWTO, 2020). The rapid growth of the tourism sector has an impact on increasing the income of countries in the world. Travel \& tourism accounted for $10.4 \%$ (USD 8.8 trillion) of the gross domestic product (GDP) and created 319 million jobs (10\% of total employment in 2018) (WTTC, 2020). It cannot be denied anymore that tourism is the most important part of a country's economy. For developed countries, in addition to making a major contribution to the sustainability of economic growth, tourism based on industry excellence also provides minimal environmental impact (Sjaifuddin, 2018). For developing countries, especially if the industrial development is not good, usually the tourism sector still has a large contribution to the state revenue (Akis, 2011). For example, in Bali, Indonesia, tourism is even able to contribute around $60-70 \%$ to the local economy, creating broad employment opportunities, and attracting investment both locally and internationally (Chong, 2020). Thus, in general, tourism is considered to have an important role in improving the quality of life (Garau-Vadell et al., 2018).

In addition to providing a positive influence economically, tourism often also presents new problems in other sectors. The main problem that often arises is the negative impact of tourism on various environmental components: biotic, abiotic, social, economic, and cultural (Cianga, 2017; Alipour \& Arefipour, 2020). The negative impact is usually closely related to mass tourism. Conventionally, mass tourism is usually associated with unsustainable use of natural resources and intensive land use (Gabarda-Mallorquí et al., 2017). One of the negative impacts of mass tourism is the increasing volume of urban solid waste (Diaz-Farina et al., 2020). For example, more than 75\% of waste production in the City of Paralimni (Cyprus) is generated by tourism activities (Zorpas et al., 2015). Another negative impact is the escalation of $\mathrm{CO}_{2}$ emissions from transportation activities (Cavallaro et al., 2017). Mass tourism contributes $4.4 \%$ to global $\mathrm{CO}_{2}$ emissions and increases an average of $3.2 \%$ per year (He et al., 2018). Improved road networks (i.e., trains, highways, airports) to support mass tourism usually have an impact on deforestation; in addition it also encourages the creation of market integration, other factors that have an impact on deforestation (Brandt \& Buckley, 2018). In the coastal zone, mass tourism threatens the existence of the beach sand dune ecosystem (Fantinato, 2019). Mass tourism also drives an increase in demand for clean water supply. This condition has a significant impact on water scarcity (Chong, 2020). In various historical objects, mass tourism has a negative impact in the form of mechanical damage and conflicts of use (Drdácký \& Drdácký, 2010).

By considering various impacts of mass tourism, the development of a more environmentally friendly tourism concept has now become an alternative. That is why people give great expectations to ecotourism, because mass tourism always presents a conflict of interest between economic development and ecological conservation (Hsu, 2019). Ecotourism as an alternative tourism concept becomes very interesting because it is considered to provide great benefits economically, socially, and environmentally (Wondirad et al., 2020). According to the International Ecotourism Society (TIES, 2015), ecotourism is defined as "responsible travel to natural areas that conserves the environment, sustains the well-being of the local people, and involves interpretation and education". The concept leads to the fulfillment of 5 ecotourism principles: environmental conservation, community participation, cultural preservation, local community empowerment, and economic benefits (Cobbinah, 2015). As a component of the green economy, ecotourism is a strategy to achieve a balance between economic and ecological interests (Anup et al., 2015), while community participation is considered as the best alternative compared to the social and environmental impacts caused by mass tourism (Southgate, 2006). The impact of ecotourism on local communities is usually identified through the economic, psychological, social, and political empowerment framework (Scheyvens \& Scheyvens, 2015). 


\section{ENTREPRENEURSHIP AND SUSTAINABILITY ISSUES}

ISSN 2345-0282 (online) http://jssidoi.org/jesi/ 2020 Volume 8 Number 2 (December) http://doi.org/10.9770/jesi.2020.8.2(4)

Ecotourism is a complex and dynamic system that involves various variables: biophysical, social, and economic. In the system, these variables interact with and depend on each other, but it also interacts complexly with other variables outside the system (Aliani et al., 2018). Complex systems also have complex problems, and only using the right methodology can be solved (Jere Jakulin, 2017). System dynamics is a methodology used to analyze complex systems through the development of representative models that reflect actual conditions (Sjaifuddin et al., 2019).

Rawa Danau is a tropical lowland swamp forest located in Serang Regency, $101 \mathrm{~km}$ from Jakarta, Indonesia. Rawa Danau is an ancient Volcano caldera of around 2.500 hectares, located at an elevation of $100 \mathrm{~m}$ above sea level (van Der Kaars et al., 2001). Ecologically, Rawa Danau is very important because it is the only tropical lowland swamp left in Java. Economically, the important role of Rawa Danau lies in its large potential as a supplier of raw water for industrial and urban areas in Serang Regency and Cilegon City (Priyanto \& Titiresmi, 2006). As an ecotourism destination, Rawa Danau has a high attraction because it has beautiful panoramas and is a habitat for various species of flora and fauna. Rawa Danau is also often used as an object of study relating to the theme of ecology, geology, biology, and the environment by researchers from various universities/research institutions both locally and internationally. Nevertheless, the existence of Rawa Danau is also faced with various challenges, including the shrinking of forest area due to land conversion; decreased water storage capacity due to sedimentation processes as well as the lack of successful conservation efforts that have an impact on the overall decline in environmental quality. Considering the various conditions above, this research is important to be carried out in order to develop a model of sustainable management of Rawa Danau. The model built will involve various biophysical, social, and economic variables and be simulated through several ecotourism zone management scenarios. For this purpose, a system dynamics approach is used to provide alternative solutions to comprehensive problem solving.

\section{Literature Review}

\subsection{Sustainable Development of Ecotourism}

According to the World Commission on Environment and Development (WCED) Report, the concept of sustainable development is identified from 3 main dimensions: social, economic, and environmental sustainability (Secundo et al., 2020). This concept is increasingly gaining worldwide attention after the United Nations adopted a global action plan for sustainable development, which contains 17 sustainable development goals (SDGs) with 169 targets (van der Waal \& Thijssens, 2020). The SDGs are a series of 17 large goals that articulate the outcomes of sustainable development (Ike et al., 2019). One of the key proposals regarding the most effective mechanism for achieving this ambitious agenda in 2030 is to focus on humanitarian-development-peace nexus (Howe, 2019). The declaration of 2017 as the International Year of Sustainable Tourism for Development by UNWTO has encouraged various related sectors (including tourism) to formulate the best strategy for achieving SDGs. According to Siakwah et al. (2019), the strategy was formulated based on the close link between tourism and SDGs (Table 1). Tourism bridges the achievement of SDGs 1, SDGs 13, and SDGs 15 through pro-poor tourism, volunteer tourism, and ecotourism. Community empowerment programs that are packaged through propoor tourism policies are proven to be able to provide economic benefits for the poor in rural areas (Torabi et al., 2019). Volunteer tourism in Tortuguero National Park Costa Rica, Mon Repos Australia, and Ubatuba Brazil is considered to have succeeded in creating broader employment opportunities for local people (Liu \& Leung, 2019). Agritourism strengthens the linkages between tourism and agriculture through the development of sustainability principles (Addinsall et al., 2017). Ecotourism is one of the mechanisms needed to strengthen adaptive capacity in order to face the challenges of the current and future climate change (Jamaliah \& Powell, 2018). Today ecotourism is growing rapidly in areas with high biodiversity because of its potential to achieve economic benefits and ecological conservation (Brandt \& Buckley, 2018). Tourism also bridges the achievement of SDGs 6, SDGs 7, and SDGs 12 through alternative tourism and responsible tourism. Alternative tourism is 


\section{ENTREPRENEURSHIP AND SUSTAINABILITY ISSUES}

ISSN 2345-0282 (online) http://jssidoi.org/jesi/ 2020 Volume 8 Number 2 (December) http://doi.org/10.9770/jesi.2020.8.2(4)

considered as an efficient mechanism for overcoming various current crises (Papageorgiou \& Lytras, 2015). Through a platform of restaurant food surplus, responsible tourism supports the consistent implementation of responsible consumption (http://ertr.tamu.edu, 2019). In a conservation perspective, ecotourism is considered as an incentive-based management intervention. This mechanism is always associated with the institutional intervention, spatial restrictions in the ecotourism zone, economic benefits obtained by local communities, and community-oriented monitoring systems (Brandt \& Buckley, 2018).

In many developing countries, ecotourism plays an important role as a source of income for local communities and reduces dependence on forests, empowering people through participation, increased access to information, strengthening organizational capacity, minimize the environmental impact, and contribute to conservation through reforestation and habitat restoration (Ma et al., 2019; Das \& Chatterjee, 2015). For example, shark watching is an ecotourism industry that is developing rapidly in Mexico, annual gross income from this activity is estimated to reach USD 12.4 million with more than 15 species of sharks successfully conserved (Cisneros-Montemayor et al., 2019). Shark ecotourism in Donsol, Philippines is able to create more than 300 jobs and offer more than 200 seasonal jobs for local fishermen so as to reduce poverty (Gallagher \& Hammerschlag, 2011). Bird watching (avitourism) has become a very popular hobby in South Africa, able to provide income of up to USD 362 per month to local communities, and is considered as a cost-effective way to create jobs, carry out conservation efforts, and develop human resources (Biggsa et al., 2011). Turtle watching at Mon Repos Conservation Park, Queensland, Australia is considered very important in promoting environmental education and promoting turtle conservation efforts (Tisdell \& Wilson, 2005). Wildlife ecotourism in Manaus, Brazil has now changed the habits of local communities from unsustainable activities to more sustainable community-based activities, increasing forest conservation, and reducing poverty (D’Cruze et al., 2017).

Table 1. Linking SDGs and tourism

\begin{tabular}{ll}
\hline \multicolumn{1}{c}{ SDGs } & \multicolumn{1}{c}{ Possible tourism to attain SDGs } \\
\hline No poverty & pro-poor tourism, volunteer tourism \\
\hline Zero hunger & agritourism \\
\hline Good health and well-being & health tourism \\
\hline Quality education & tourism in-house training courses and skills development of local communities \\
\hline Gender equality & inclusive tourism \\
\hline Clean water and sanitation & responsible tourism \\
\hline Affordable and clean energy & alternative tourism \\
\hline Decent work and economic growth & local economic development through tourism \\
\hline Industry, innovation and infrastructure & tourism super-structure \\
\hline Reduced inequalities & inbound and outbound tourism, inclusive tourism, pro-poor tourism \\
\hline Sustainable cities and communities & urban tourism, community-based tourism, inclusive tourism \\
\hline Responsible consumption and production & responsible tourism, green tourism \\
\hline Climate action & ecotourism \\
\hline Life below water & aquatourism \\
\hline Life on land & sustainable tourism, ecotourism \\
\hline Peace, justice and strong institutions & inclusive tourism, peace through tourism, justice tourism \\
\hline Partnerships for the goals & justice tourism, collaborative community-based tourism \\
\hline & (Siakwah et al., 2019)
\end{tabular}

\subsection{Threat to Freshwater Swamp Forest}

Freshwater swamp forests (FSF) throughout the world are now facing a very serious threat. Various natural and anthropogenic factors are often a threat to FSF and have an impact on decreasing ecological function (Baustian et al., 2018). These natural factors are usually natural disasters, while the anthropogenic factors are overharvesting, incorrect harvesting techniques, conversion to agricultural land, and land burning (Omagor, 1999). Forest degradation is one of the trigger factors for land fires during the dry season (Dwomoh et al., 2019). The excessive 
ENTREPRENEURSHIP AND SUSTAINABILITY ISSUES

ISSN 2345-0282 (online) http://jssidoi.org/jesi/ 2020 Volume 8 Number 2 (December) http://doi.org/10.9770/jesi.2020.8.2(4)

utilization of FSF will be very detrimental especially for flora and fauna that are sensitive to the fluctuations in environmental factors (Sun et al., 2016). FSF is a zone rich in biodiversity and provides a variety of ecosystem services: carbon storage, water sources, germplasm sources, and food sources (Igu \& Marchant, 2017). In addition to responding to environmental changes, biodiversity is also a predictor of various ecosystem functions that are important for maintaining human well-being (Mori et al., 2017). FSF is part of the tropical rain forest and has an important contribution as climate change modulators. As a carbon storage zone, the FSF in the Niger Delta, for example, is capable of storing carbon on average 228.28 ton/hectare, a large storage capacity (Igu \& Marchant, 2016). The ability to store carbon by the FSF depends on: 1) the ability of flora to absorb carbon from the atmosphere; 2) the material cycle flowing from living biota to dead biota; 3) subsequent deposition and storage processes in the earth (Harrison, 2013).

Changes in FSF biodiversity are mainly caused by 2 important factors: natural and anthropogenic drivers of change (Fig. 1). Both of these factors give effect to landscape modification in the form of hydrological changes, forest degradation, and forest regeneration. The dashed line in the figure means that the FSF is resistant to the invasion of new species, so landscape modification is a more influential factor in biodiversity changes. Landscape modification will cause population change through mechanisms: food resource changes, dispersal constraints, and behavior changes. Meanwhile population change will form mutually influencing relationships with community change and species interaction. On the other hand, overharvesting is one of the important anthropogenic factors that will directly affect population change.

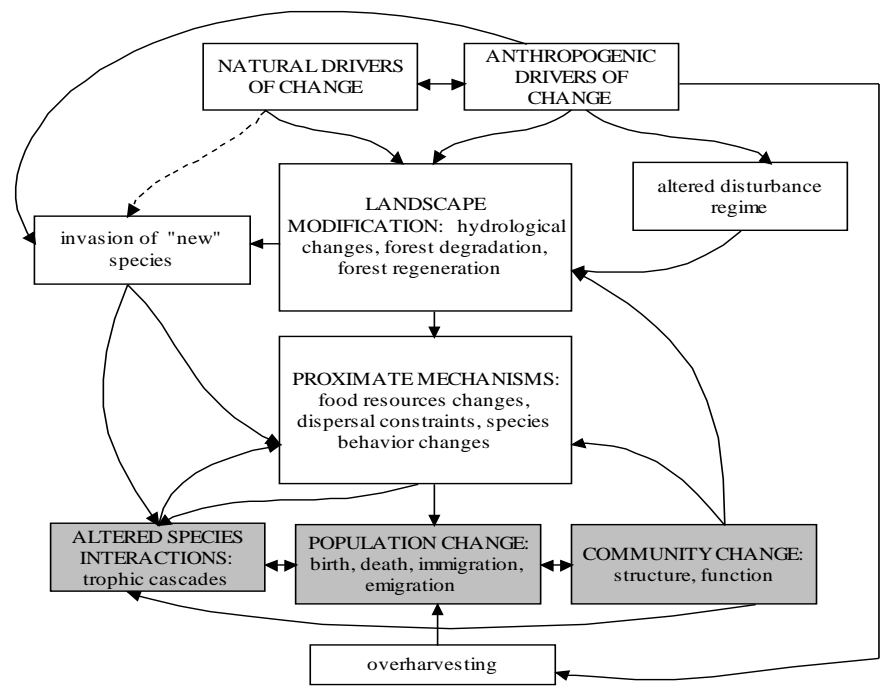

Fig. 1. Effects of natural and athropogenic drivers of change on the biodiversity of FSF (Harrison, 2013).

\subsection{System Dynamics}

System dynamics (SD) was first introduced in the 1950s by Forrester (Yu et al., 2019). Forrester developed a modeling and illustrated how a policy can affect the stability of industrial systems (Cesar et al., 2020). SD is a sophisticated methodology used to represent complex feedback structures (Teng et al., 2018) so it is very useful to understand cross-disciplinary issues (Tan et al., 2018). SD modeling is characterized by the existence of nonlinear relationships and feedback between components in a system and is very suitable to be used to model complex socioeconomic phenomena (Wit et al., 2018). Sustainable management of ecotourism zone has characteristics that are interdisciplinary, dynamics, and non-linear so that it will be very suitable if the model uses 


\section{ENTREPRENEURSHIP AND SUSTAINABILITY ISSUES}

ISSN 2345-0282 (online) http://jssidoi.org/jesi/ 2020 Volume 8 Number 2 (December) http://doi.org/10.9770/jesi.2020.8.2(4)

SD. As an aspect of system theory, SD enables the modeller to understand the nonlinearities of the system through structural modeling including circular feedback or time delayed relationships (Daneshzand et al., 2019). The use of the SD methodology is based on three main principles: 1) the development of model structure that determines the system behavior, 2) the involvement of soft variables in the model structure, 3) the understanding of mental models that produce significant leverage (Saavedra M. et al., 2018). Utilization of SD has several advantages, including: (1) visualizing the causal relationship between variables, (2) understanding the impact of delays on the system, and (3) understand the system's response to several different scenarios (Zapata et al., 2019). The researchers used SD to develop policies suitable for problem solving in various dimensions of ecotourism. To simulate a low-carbon ecotourism activity, He et al. (2018) has created a system dynamics design that involves ecotourism activities, carbon waste, and ecology using a case study in Western China. To improve coastal ecosystem management, You et al. (2018) has conducted a simulation of landscape changes using several management scenarios and case studies in Shinduri coastal zone, South Korea. Pizzitutti et al. (2017) uses SD as a decision-support system to provide recommendations to policy makers in managing the Galapagos Islands as an integrated system. Some other researchers who use SD simulations in the field of ecotourism include Lu et al. (2019) who evaluate the effect of socio-economic factors on ecological security systems of coastal tourism cities, Tan et al. (2018) modeling coastal zone management for sustainable tourism, Xu \& Dai (2012) explores the policies of a world inheritance village to support sustainable tourism.

\section{Method}

Tourism is a goal-oriented soft system, built by integrated components e.g. tourists, demand, supply, information, as well as social, material, and financial relations between the existing subsystems (Jere Jakulin, 2017). This study uses SD as a robust methodology to explore long-term ecotourism development policies (Xu \& Dai, 2012). SD provides answers to the 'what-if' question through a feedback loop that is built between variables in the system (Sukholthaman \& Sharp, 2016). The SD concept is presented simply through graphs and basic formulas and does not use complicated mathematical formulas (El-Sefy et al., 2019). SD methodology is used through the steps of modeling and qualitative methods as follows (Luna-Reyes \& Andersen, 2003): 1) conceptualization, consists of 2 steps: problem definition and system conceptualization. In this research, the methods used to identify problems and describe the dynamic hypotheses are interviews and content analysis; 2) model formulation. In this research, the methods used to obtain parameters and policies are interviews and content analysis; while to construct the model formulation is grounded theory; 3 ) testing, consists of 2 steps: analysis of model behavior and model evaluation. In this research, the method used to justify the structure of the model is expert judgment; 4) implementation, consists of 2 steps: policy analysis and model use. At the implementation stage, the method used to test the policies is experimental approach; while to generate discussion among stakeholders is focus group. This research is only carried out until the $3^{\text {rd }}$ stage.

SD has a set of qualitative tools that are used to analyze various dynamic processes, e.g., causal loop diagram (CLD) and flow diagram (FD) (Honti et al., 2019). CLD is a structure that functions to describe the feedback relationship between variables qualitatively (Moeis et al., 2020). In CLD there are two types of loops: reinforcing loop (R) and balancing loop (B) (Fig. 2 (a)). A strengthening relationship (R) will occur if X increases, then Y also increases; an increase in $\mathrm{Y}$ will cause an increase in $\mathrm{X}$ again. A balancing relationship (B) will occur if $\mathrm{Y}$ increases, then $\mathrm{Z}$ also increases; increasing $\mathrm{Z}$ will decrease $\mathrm{Y}$ (Sjaifuddin, 2020). After the CLD has been formed, an FD (Figure 2 (b)) is built. FD is a dynamic model structure built by several components: levels, rates, and auxiliaries (Walrave \& Raven, 2016). In the FD, information accumulation in the system is centered on the levels (stocks); the rate of change in the volume of information is represented by the rates (flows); while intermediate variables that contain various calculations involving other variables are shown by auxiliaries. There are two other components in FD: constants and connectors. Constants are fixed values that affect certain variables, while connectors show links between components in the model. 


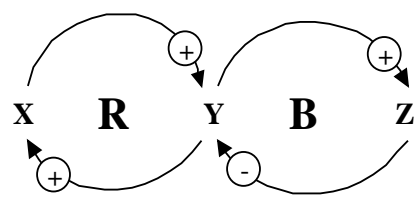

(a)

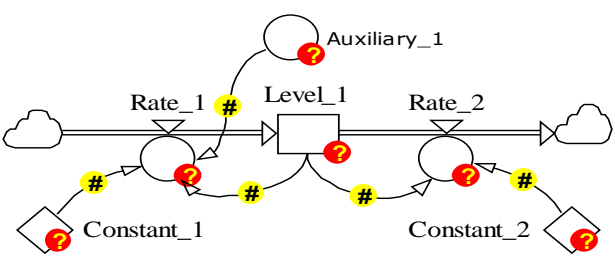

(b)

Fig. 2. Simple causal loop diagram (a) and flow diagram (b)

\section{Result and Discussion}

\subsection{Causal Loop Diagram}

CLD on sustainable management of freshwater swamp forest as an ecotourism destination in Indonesia is presented in Fig. 3. This CLD has 3R and 2B. R1 shows a mutually reinforcing relationship between environmental investment and local community income. The greater the environmental investment, the intensity of local community empowerment will be higher; this condition drives the increasing local community income. Conversely, a higher local community income will encourage more intensive conservation efforts; this condition drives the greater environmental investment. R2 shows the mutually reinforcing relationship between environmental investment and community independence. The greater the environmental investment, the intensity of local community empowerment will be higher; this condition then drives higher access to resources, so that the impact on community independence is also higher. Conversely, a higher community independence will encourage greater environmental investment. R3 shows the mutually reinforcing relationship between environmental investment and conservation efforts. The greater the environmental investment, the higher the conservation efforts. Conversely, the higher the conservation efforts, the greater the environmental investment.

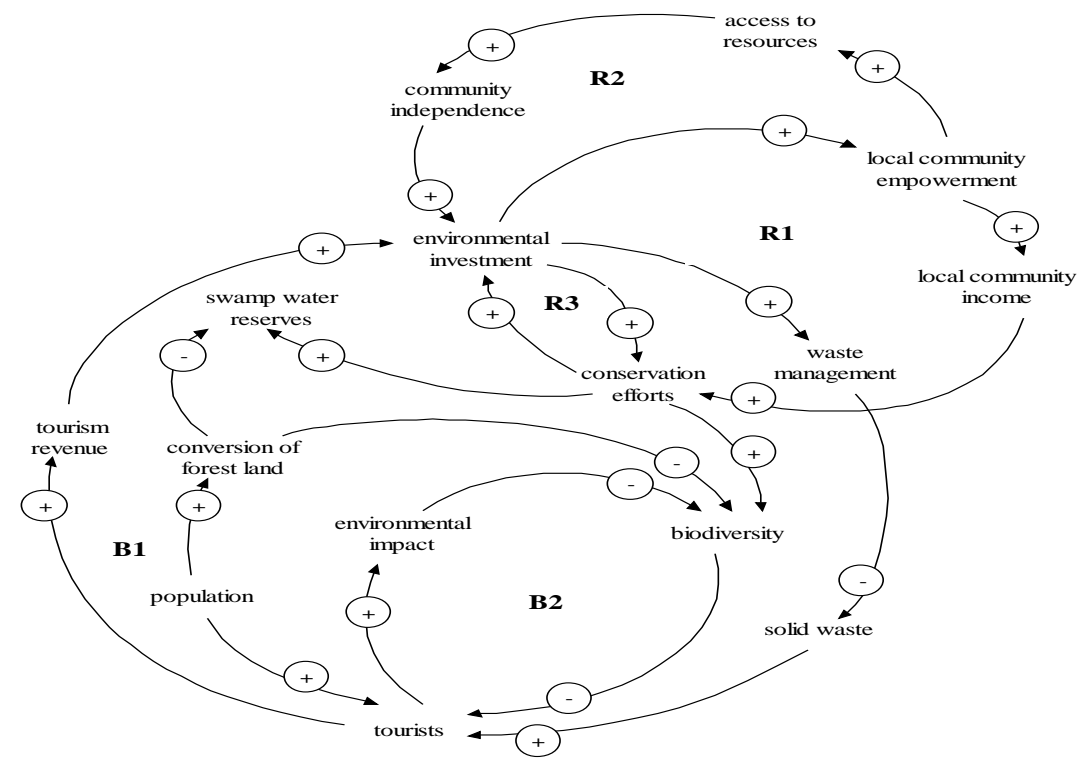

Fig. 3. CLD on sustainable management of freshwater swamp forest as an ecotourism destination in Indonesia 
B1 shows a mutually balancing relationship between tourists and waste management. The greater the number of tourists, the greater the tourism revenue; this condition then encourages greater environmental investment, which will be used for more intensive waste management. Conversely, the higher intensity of waste management will cause a lower volume of solid waste; this condition will encourage a greater number of tourists. B2 shows a mutually balancing relationship between tourists and biodiversity. The greater number of tourists will have a greater environmental impact; this will lead to lower biodiversity. Conversely, low biodiversity will cause a decreasing number of tourists.

\subsection{Flow Diagram}

Flow diagrams are presented in Fig. 4 is built based on the CLD in Fig. 3, and named Freshwater swamp forest model (FSFM). FSFM has 3 sub-models: social sub-model (red), economic sub-model (blue), and biophysical sub-model (black). The social sub-model is a main model that has 1 level: 'tourists' and 2 auxiliaries: 'local community empowerment' and 'environmental impact management'. The economic sub-model is a co-model that has 2 levels: 'local community income' and 'environmental investment'. The biophysical sub-model is a co-model that has 4 levels: 'conversion of forest land', 'swamp water reserves', 'solid waste', and 'biodiversity'.

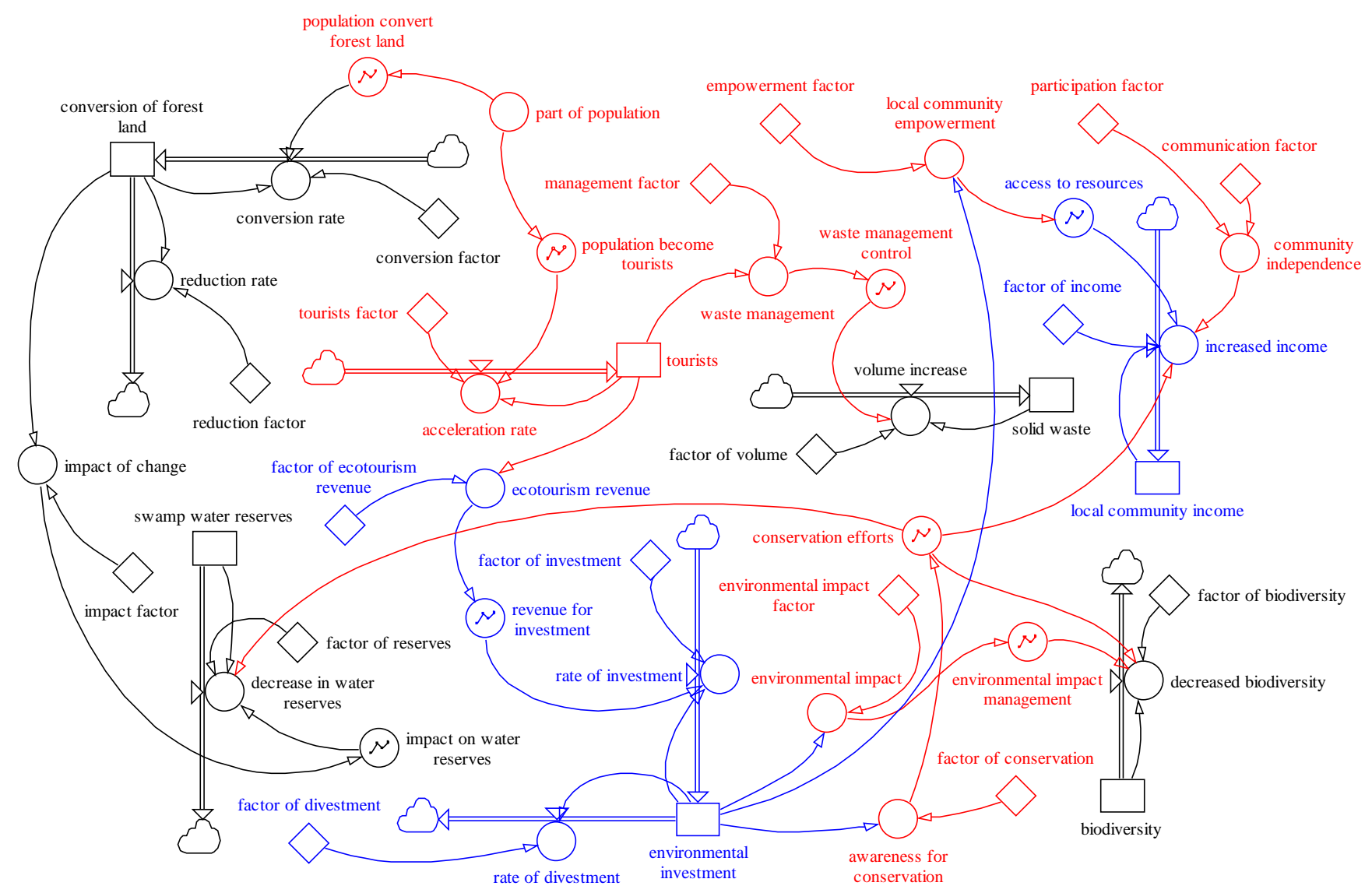

Fig. 4. Freshwater swamp forest model (FSFM)

\section{'Tourists'}

Based on Fig. 4, 'tourists' is a stock with an initial value of 12.584 people. 'Tourists' increase through the 'acceleration rate' which functions as a flow that has the equation: tourists*'tourists factor'*'population become tourists'. The graph function 'population become tourists' has an equation: GRAPHCURVE 


\section{ENTREPRENEURSHIP AND SUSTAINABILITY ISSUES}

ISSN 2345-0282 (online) http://jssidoi.org/jesi/ 2020 Volume 8 Number 2 (December) http://doi.org/10.9770/jesi.2020.8.2(4)

(population; $0 ; 0,1 ;\{0,127 ; 0,17 ; 0,22 ; 0,3 ; 0,34 ; 0,39 ; 0,51 ; 0,74 ; 0,827 ; 0,84 / / \mathrm{Min}: 0 ; \mathrm{Max}: 1 / /\})$. As a constant, 'tourists factor' has a value of $0.151 /$ year. 'Part of population' is an auxiliary which has a value of 2 . 'Population convert forest land' is a graph function that has an equation: GRAPHCURVE (population; $0 ; 0,1 ;\{0,32 ; 0,36 ; 0,367 ; 0,37$; $0,387 ; 0,467 ; 0,65 ; 0,807 ; 0,87 ; 0,89 / / \mathrm{Min}: 0 ; \mathrm{Max}: 1 / /\})$. As an auxiliary, 'waste management' has an equation: tourists*'management factor'. 'Waste management control' is a graph function that has an equation: GRAPHCURVE('waste management';0;0,1;\{0,52;0,307;0,167;0,11;0,1;0,19;0,33;0,45;0,49;0,4//Min:0;Max:1// $\}$ ). As a constant, 'management factor' has a value of 1.41 / people. All values and equations related to 'tourists' are shown in Table 2.

Table 2. Values and equations related to 'tourists'

\begin{tabular}{lll}
\hline Components & Values & Equations \\
\hline tourists (stock) & 12584 people & \\
\hline acceleration rate (flow) & & tourists*'tourists factor'*'population become tourists' \\
\hline tourists factor (constant) & $0,151 /$ year & \\
\hline $\begin{array}{l}\text { population become tourists (graph } \\
\text { function) }\end{array}$ & GRAPHCURVE(population; $0 ; 0,1 ;\{0,127 ; 0,17 ; 0,22 ; 0,3 ; 0,34 ; 0,39 ;$ \\
\hline part of population (auxiliary) & 0,2 & 0,$51 ; 0,74 ; 0,827 ; 0,84 / /$ Min:0;Max:1//\}) \\
\hline population convert forest land & & GRAPHCURVE(population;0;0,1;\{0,32;0,36;0,367;0,37;0,387; \\
(graph function) & & $0,467 ; 0,65 ; 0,807 ; 0,87 ; 0,89 / /$ Min:0;Max: $1 / /\})$ \\
\hline waste management (auxiliary) & tourists'management factor' \\
\hline waste management control (graph & & GRAPHCURVE('waste \\
function) & & management';0;0,1;\{0,52;0,307;0,167;0,11;0,1;0,19; \\
& & $0,33 ; 0,45 ; 0,49 ; 0,4 / /$ Min:0;Max:1// $\})$ \\
\hline management factor (constant) & $1,41 /$ people & \\
\hline
\end{tabular}

\section{'Local community empowerment'}

Fig. 4 shows that 'local community empowerment' is an auxiliary with an equation: 'empowerment factor'*'environmental investment'. 'Community independence' is also an auxiliary that has an equation: 'participation factor' * 'communication factor'. As a constant, 'communication factor' has a value of 5.11 / people; 'participation factor' is 0.05 people; while the 'empowerment factor' is $0.11 /$ percent. All values and equations related to 'local community empowerment' are shown in Table 3.

Table 3. Values and equations related to 'local community empowerment'

\begin{tabular}{lll}
\hline Components & Values & Equations \\
\hline local community empowerment (auxiliary) & & 'empowerment factor'*'environmental investment' \\
\hline community independence (auxiliary) & & 'participation factor'*'communication factor' \\
\hline communication factor (constant) & $5,11 /$ people & \\
\hline participation factor (constant) & 0,05 people & \\
\hline empowerment factor (constant) & $0,11 /$ percent & \\
\hline
\end{tabular}

\section{'Environmental impact management'}

According to Fig. 4, 'environmental impact management' is a graph function that has an equation: GRAPHCURVE('environmental impact';0;0,1; $\{0,15 ; 0,22 ; 0,287 ; 0,34 ; 0,38 ; 0,407 ; 0,53 ; 0,66 ; 0,71 ; 0,66 / /$ Min:0;Max: $1 / /\})$. 'Environmental impact' is an auxiliary that has an equation: 'environmental investment'*'environmental impact factor'. 'Awareness for conservation' is also an auxiliary with an equation: 'environmental investment'*'factor of conservation'. The 'conservation efforts' is a graph function with an equation: GRAPHCURVE('awareness for conservation';0; 0,1; $\{0,207 ; 0,227 ; 0,22 ; 0,207 ; 0,19 ; 0,267 ; 0,467 ; 0,77 ; 0,84 ; 0,847 / /$ Min:0;Max:1//\}). As a constant, 'environmental impact factor' has a value of $0.000000021 /$ percent; while the 'factor of conservation' is 0.11 / percent. All values and equations related to 'environmental impact management' are shown in Table 4. 


\section{ENTREPRENEURSHIP AND SUSTAINABILITY ISSUES}

ISSN 2345-0282 (online) http://jssidoi.org/jesi/ 2020 Volume 8 Number 2 (December) http://doi.org/10.9770/jesi.2020.8.2(4)

\section{'Local community income'}

Based on Fig. 4, 'local community income' is a stock with an initial value of 3,5 million Rupiah. 'Local community income' increases through 'increased income', a flow that has an equation: 'community independence'*'access to resources'*'conservation efforts'*'local community income'*'factor of income'. 'Access to resources' is a graph function with an equation: GRAPHCURVE('local community empowerment'; $0 ; 0,1 ;\{0,91 ; 0,287 ; 0,23 ; 0,24 ; 0,28 ; 0,45 ; 0,53 ; 0,607 ; 0,69 ; 0,71 / / \mathrm{Min}: 0 ; \mathrm{Max}: 1 / /\})$. As a constant, 'factor of income' has a value of 1,11 1/year. All values and equations related to 'local community income' are shown in Table 5.

Table 4. Values and equations related to 'environmental impact management'

\begin{tabular}{|c|c|c|}
\hline Components & Values & Equations \\
\hline $\begin{array}{l}\text { environmental impact management } \\
\text { (graph function) }\end{array}$ & & $\begin{array}{l}\text { GRAPHCURVE('environmental } \\
\text { impact';0;0,1;\{0,15;0,22;0,287;0,34;0,38;0,407; } \\
0,53 ; 0,66 ; 0,71 ; 0,66 / / \mathrm{Min}: 0 ; \operatorname{Max}: 1 / /\})\end{array}$ \\
\hline environmental impact (auxiliary) & & 'environmental investment'*'environmental impact factor' \\
\hline awareness for conservation (auxiliary) & & 'environmental investment'*'factor of conservation' \\
\hline conservation efforts (graph function) & & $\begin{array}{l}\text { GRAPHCURVE('awareness for } \\
\text { conservation';0;0,1;\{0,207;0,227;0,22;0,207;0,19;0,267; } \\
0,467 ; 0,77 ; 0,84 ; 0,847 / / \text { Min:0;Max:1// }\})\end{array}$ \\
\hline environmental impact factor (constant) & $\begin{array}{l}0,00000002 \\
1 / \text { percent } \\
\end{array}$ & \\
\hline factor of conservation (constant) & $0,11 /$ percent & \\
\hline
\end{tabular}

Table 5. Values and equations related to 'local community income'

\begin{tabular}{lll}
\hline Components & Values & Equations \\
\hline local community income (stock) & 3.500 .000 & \\
& Rupiah (Rp) & \\
\hline increased income (flow) & & 'community independence'*'access to resources'*'conservation efforts'*'local \\
& & community income'*'factor of income' \\
\hline access to resources (graph function) & & GRAPHCURVE('local community empowerment'; \\
& & $0 ; 0,1 ;\{0,91 ; 0,287 ; 0,23 ; 0,24 ; 0,28 ; 0,45 ;$ \\
& & $0,53 ; 0,607 ; 0,69 ; 0,71 / /$ Min:0;Max: $1 / /\})$ \\
\hline factor of income (constant) & $1,111 /$ year & \\
\hline
\end{tabular}

\section{'Environmental investment'}

Based on Fig. 4, 'environmental investment' is a stock with an initial value of 0,2 percent. 'Environmental investment' increases through 'rate of investment', a flow that has an equation: 'revenue for investment'*'environmental investment'*'factor of investment'. 'Environmental investment' also decreases through 'rate of divestment', a flow that has an equation: 'environmental investment'*'factor of divestment'. As a constant, 'factor of investment' has a value of 0,7 1/year; while the 'factor of divestment' is 0,1 1/year. 'Revenue for investment' is a graph function with an equation: GRAPHCURVE('ecotourism revenue' $; 0 ; 0,1 ;\{0,1 ; 0,2 ; 0,2 ; 0,227 ; 0,28 ; 0,45 ; 0,76 ; 0,88 ; 0,9 ; 0,9 / /$ Min:0;Max:1//\}). 'Ecotourism revenue' is an auxiliary with an equation: ecotourists*'factor of ecotourism revenue'. As a constant, 'factor of ecotourism revenue' has a value of 0,0006 1/people. All values and equations related to 'environmental investment' are shown in Table 6.

\section{'Conversion of forest land'}

According to Fig. 4, 'conversion of forest land' is a stock with an initial value of 8,57 hectares. This stock increases through 'conversion rate', a flow that has an equation: 'population convert forest land'*'conversion of forest land'*'conversion factor'. This stock decreases through 'reduction rate', a flow that has an equation: 'conversion of forest land'*'reduction factor'. As a constant, 'reduction factor' has a value of 0,3 1/year; while the 'conversion factor' is 0,001 1/year, and 'impact factor' is $0,21 /$ hectare. 'Impact of change' is an auxiliary with an 


\section{ENTREPRENEURSHIP AND SUSTAINABILITY ISSUES}

ISSN 2345-0282 (online) http://jssidoi.org/jesi/ 2020 Volume 8 Number 2 (December) http://doi.org/10.9770/jesi.2020.8.2(4)

equation: 'conversion of forest land'*'impact factor'. All values and equations related to 'conversion of forest land' are shown in Table 7.

Table 6. Values and equations related to 'environmental investment'

\begin{tabular}{|c|c|c|}
\hline Components & Values & Equations \\
\hline environmental investment (stock) & 0,2 percent & \\
\hline rate of investment (flow) & & 'revenue for investment'*'environmental investment'*'factor of investment' \\
\hline rate of divestment (flow) & & 'environmental investment'*'factor of divestment' \\
\hline factor of investment (constant) & $0,71 /$ year & \\
\hline factor of divestment (constant) & $0,11 /$ year & \\
\hline $\begin{array}{l}\text { factor of ecotourism revenue } \\
\text { (constant) }\end{array}$ & $\begin{array}{l}0,0006 \\
1 / \text { people }\end{array}$ & \\
\hline ecotourism revenue (auxiliary) & & ecotourists*'factor of ecotourism revenue' \\
\hline $\begin{array}{l}\text { revenue for investment (graph } \\
\text { function) }\end{array}$ & & $\begin{array}{l}\text { GRAPHCURVE('ecotourism revenue' } \\
; 0 ; 0,1 ;\{0,1 ; 0,2 ; 0,2 ; 0,227 ; 0,28 ; 0,45 ; 0,76 ; 0,88 ; 0,9 ; 0,9 / / \mathrm{Min}: 0 ; \mathrm{Max}: 1 / /\})\end{array}$ \\
\hline
\end{tabular}

Table 7. Values and equations related to 'conversion of forest land'

\begin{tabular}{lll}
\hline Components & Values & Equations \\
\hline Conversion of forest land (stock) & 8,57 hectare & \\
\hline conversion rate (flow) & & $\begin{array}{l}\text { 'population convert forest land'*'conversion of forest land'*'conversion } \\
\text { factor' }\end{array}$ \\
\hline reduction rate (flow) & 'conversion of forest land'*'reduction factor' \\
\hline reduction factor (constant) & $0,31 /$ year & \\
\hline conversion factor (constant) & $0,0011 /$ year & \\
\hline impact of change (auxiliary) & & 'conversion of forest land'*'impact factor' \\
\hline impact factor (constant) & $0,21 /$ hectare & \\
\hline
\end{tabular}

\section{'Swamp water reserves'}

Fig. 4 shows that 'swamp water reserves' is a stock with an initial value of 500 million $\mathrm{m}^{3}$ (expert estimates). This stock decreases through 'decrease in water reserves', a flow that has an equation: 'impact on water reserves'*'conservation efforts'*'swamp water reserves'*'factor of reserves'. 'Impact on water reserves' is a graph function with an equation: GRAPHCURVE('impact of change'; $0 ; 0,1 ;\{0,147 ; 0,4 ; 0,547 ; 0,63 ; 0,727 ; 0,78 ; 0,81$; 0,82;0,847;0,85//Min:0;Max:1//\}). As a constant, 'factor of reserves' has a value of 0,000001 1/year. All values and equations related to 'swamp water reserves' are shown in Table 8.

Table 8. Values and equations related to 'swamp water reserves'

\begin{tabular}{lll}
\hline Components & Values & Powersim Equations \\
\hline swamp water reserves (stock) & $500.000 .000 \mathrm{~m}^{3}$ & \\
\hline decrease in water reserves (flow) & & $\begin{array}{l}\text { 'impact on water reserves'*'conservation efforts'*'swamp water } \\
\text { reserves'*'factor of reserves' }\end{array}$ \\
\hline factor of reserves (constant) & 0,000001 1/year & \\
\hline impact on water reserves (graph & & $\begin{array}{l}\text { GRAPHCURVE('impact of } \\
\text { change';0;0,1; } 0,147 ; 0,4 ; 0,547 ; 0,63 ; 0,727 ; 0,78 ; 0,81 ; 0,82 ; 0,847 ; 0,8 \\
\text { function) }\end{array}$ \\
& & $5 / /$ Min:0;Max:1//\}) \\
\hline
\end{tabular}

\section{'Solid waste'}

Based on Fig.4, it is known that 'solid waste' is a stock with an initial value of 62.986 kilograms. This stock increases through 'volume increase', a flow that has an equation: 'waste management control'*'solid waste'*'factor of volume'. As a constant, 'factor of volume' has a value of 0,00003 1/year. All values and equations related to 'solid waste' are shown in Table 9. 
ENTREPRENEURSHIP AND SUSTAINABILITY ISSUES

ISSN 2345-0282 (online) http://jssidoi.org/jesi/ 2020 Volume 8 Number 2 (December) http://doi.org/10.9770/jesi.2020.8.2(4)

Table 9. Values and equations related to 'solid waste'

\begin{tabular}{lll}
\hline Components & Values & Equations \\
\hline solid waste (stock) & 62.986 kilograms & \\
\hline volume increase (flow) & & 'waste management control'*'solid waste'*'factor of volume' \\
\hline factor of volume (constant) & 0,00003 1/year & \\
\hline
\end{tabular}

\section{'Biodiversity'}

According to Fig. 4, 'biodiversity' is a stock with an initial value of 95 percent (expert estimates). This stock decreases through 'decreased biodiversity', a flow that has an equation: 'conservation efforts'*'environmental impact management'*biodiversity*'factor of biodiversity'. As a constant, 'factor of biodiversity' has a value of 0,01 1/year. All values and equations related to 'biodiversity' are shown in Table 10.

Table 10. Values and equations related to 'biodiversity'

\begin{tabular}{lll}
\hline Components & Values & Equations \\
\hline Biodiversity (stock) & 95 percent & \\
\hline decreased biodiversity (flow) & & $\begin{array}{l}\text { 'conservation efforts'*'environmental impact } \\
\text { management'*biodiversity*'factor of biodiversity' }\end{array}$ \\
\hline factor of biodiversity (constant) & $0,011 /$ year & \\
\hline
\end{tabular}

\subsection{Model simulation}

A model simulation is performed to find out the system behavior. By using the euler method (fixed step) at the $1^{\text {st }}$ order, the simulation starts in 2020 until 2030. In this research, the simulation uses 3 scenarios of ecotourism management: 1) deep ecotourism which is oriented towards very strong/strong sustainability, 2) shallow ecotourism oriented to weak sustainability, and 3) mass tourism which is oriented towards very weak sustainability (Acott et al., 1998). There are several assumptions used in the simulation: 1) stable and controlled biophysical environmental conditions (e.g., no disaster occurs), 2) consistent tourism policies, 3) maintaining political and security stability.

The growth of tourists during the 10-year simulation is shown in Fig. 5(a). In the mass tourism scenario, the number of tourists grows exponentially, consequently at the end of the simulation period the number of tourists increased by more than $240 \%$ (from 12,584 peoples to 42,853 people). In the shallow ecotourism scenario, the number of tourists increased by $103.3 \%$ (from 12,584 people to 25,587 people), while in the deep ecotourism scenario, the number of tourists increased by $38.4 \%$ (from 12,584 people to 17,411 people). The large number of tourists will increase the consumption of tourism resources and produce a large volume of waste, because mass tourism greatly exploits natural resources and the environment (Cianga, 2017). In addition, it also becomes a heavy social burden due to increased crime, prostitution, and other social problems (Das \& Chatterjee, 2015). Mass tourism in Bali, for example, has had a significant impact: 1) a big burden on waste management, 2) traffic congestion, 3) cultural dilution, 4) tourist misbehaviour (Chong, 2020). In the shallow ecotourism scenario, the number of tourists increased by $103.3 \%$ (from 12,584 people to 25,587 people). This increase is considered still quite large and has the potential to burden the environment. In the deep ecotourism scenario, the number of tourists increased by $38.4 \%$ (from 12,584 people to 17,411 people). This condition is considered as a fairly logical growth because it is not too high so it does not burden the environment. 


\section{ENTREPRENEURSHIP AND SUSTAINABILITY ISSUES}

ISSN 2345-0282 (online) http://jssidoi.org/jesi/ 2020 Volume 8 Number 2 (December) http://doi.org/10.9770/jesi.2020.8.2(4)

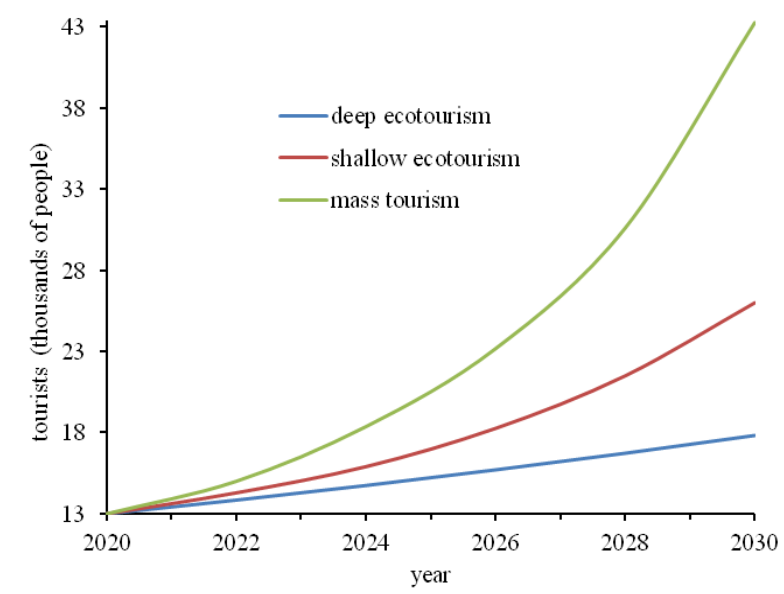

(a)

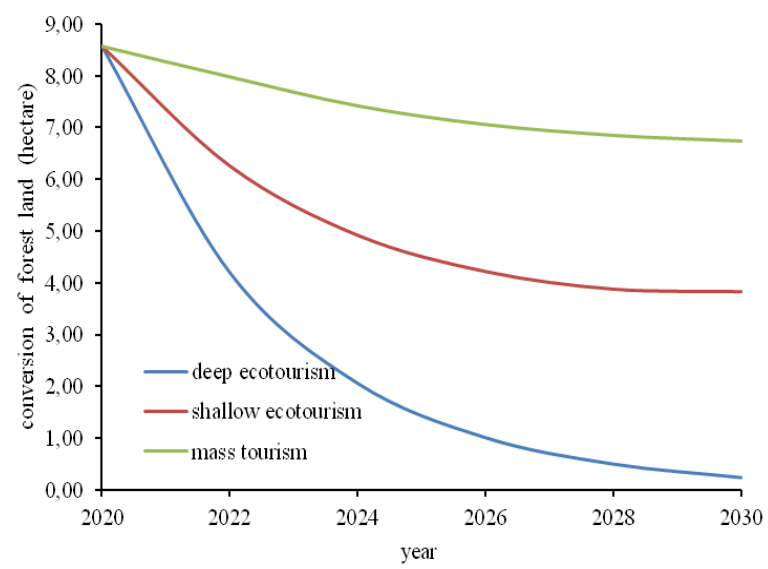

(b)

Fig. 5. Growth patterns of tourist numbers (a) and conversion of forest land (b) according to 3 scenarios of ecotourism management

Decreased area of converted forest land during the 10-year simulation is shown in Figure 5(b). In the deep ecotourism scenario, almost all converted forest land (97.2\%) has been successfully reforested (from 8.57 hectares in 2020 remaining 0.24 hectare in 2030). This condition shows that the deep ecotourism scenario has successfully restored forest functions well. In the mass tourism scenario, the area of converted forest land only decreased by 21.4\% (from 8.57 hectares in 2020 to 6.74 hectares in 2030); while in the shallow tourism scenario, the area of converted forest land decreased by 55.3\% (from 8.57 hectares in 2020 to 3.83 hectares in 2030). This condition shows that the two scenarios have not been able to reforest converted land. In relation to climate change mitigation, maintaining forest functions is very important. Research by Suwarno et al. (2018) shows that forest conversion moratorium in West Kotawaringin and Kapuas Regency (Indonesia) is able to reduce the potential of $\mathrm{CO}_{2}$ emissions by 15\%-23\%. In another aspect, forest land conversion will also affect the number and composition of litterfall. This condition will certainly affect the content of organic matter and soil nutrient cycles which will then have an impact on soil microbial diversity (Yu et al., 2012). Deforestation also results in lower soil quality, for example, it was demonstrated by decreasing levels of organic carbon and microbial biomass carbon (Rasouli-Sadaghiani et al., 2018).

The growth of local community income during the 10-year simulation is shown in Fig. 6(a). In the deep ecotourism scenario, there was a $28.6 \%$ growth in local community income (from Rp. 3,500,000 in 2020 to Rp. $4,500,522$ in 2030). In the shallow ecotourism scenario, the growth of local community income is only $16.8 \%$ (from Rp. 3,500,000 in 2020 to Rp. 4,089,368 in 2030); while in the mass tourism scenario, there was a very significant decrease in local community income: 49.3\% (from Rp. 3,500,000 in 2020 to only Rp. 1,775,644 in 2030). This condition shows that the deep ecotourism scenario is the best alternative for increasing local community income. This is in line with the principle of ecotourism that develops in areas with high biodiversity but is still able to achieve economic benefits and ecological conservation (Brandt \& Buckley, 2018). Ecotourism in this region is still able to maintain traditional values, create jobs for local people, and provide income for people who were previously unemployed (Scheyvens \& Scheyvens, 2015). Declining local community income in the mass tourism scenario is possible because almost all dimensions of mass tourism are controlled by large capital owners, so that the local community is marginalized. 


\section{ENTREPRENEURSHIP AND SUSTAINABILITY ISSUES}

ISSN 2345-0282 (online) http://jssidoi.org/jesi/ 2020 Volume 8 Number 2 (December) http://doi.org/10.9770/jesi.2020.8.2(4)

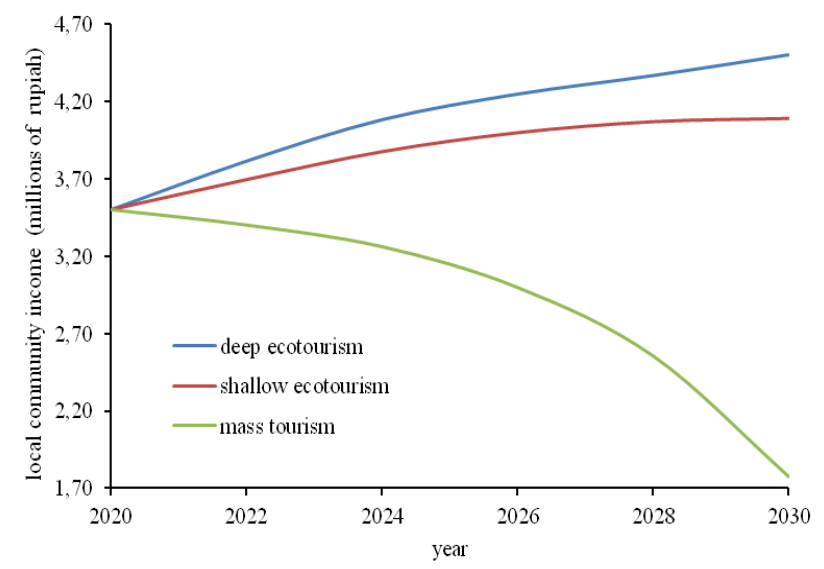

(a)

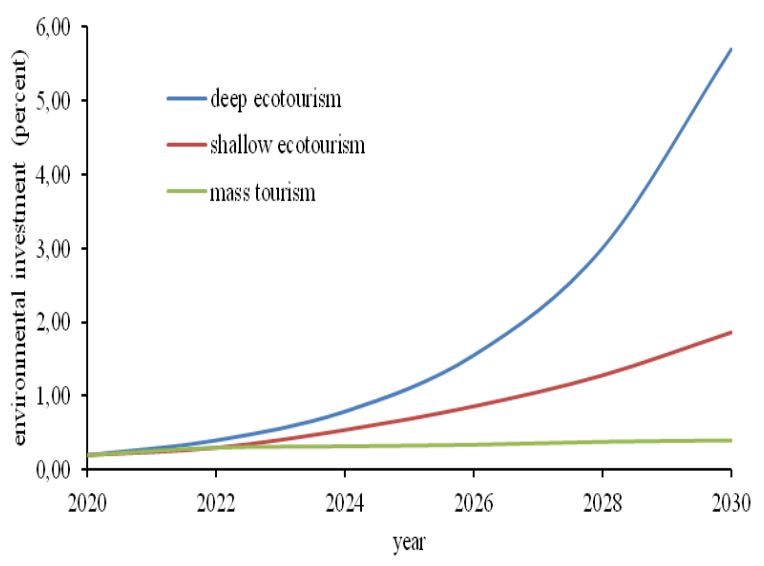

(b)

Fig. 6. Growth patterns of local community income (a) and environmental investment (b) according to 3 scenarios of ecotourism management

Growth in environmental investment during the 10-year simulation is shown in Figure 6 (b). In the deep ecotourism scenario, there is an environmental investment growth of 2,745\% (from $0.2 \%$ in 2020 to $5.69 \%$ in 2030). In the shallow ecotourism scenario there is an $830 \%$ growth (from $0.2 \%$ in 2020 to 1.86\% in 2030); while in the mass tourism scenario $100 \%$ growth occurs (from $0.2 \%$ in 2020 to $0.4 \%$ in 2030). This condition shows that the deep ecotourism scenario is the best alternative for environmental investment growth. A well-grown environmental investment will trigger an increase in environmental performance. Environmental performance is an effective solution to reduce problems due to over-utilization of resources (Jin-Fang et al., 2020). Environmental investment implemented in the service sector greatly impacts on reducing costs through more efficient use of resources such as energy and water. Environmental investment has now become the choice because with only a small investment, measurable economic benefits will soon be obtained (Bagur-Femenías et al., 2015).

The decline in biodiversity during the 10-year simulation is shown in Figure 7 (a). In the deep ecotourism scenario, there is a relatively small reduction in biodiversity $(0.33 \%$ ) (from $95.0 \%$ in 2020 to $94.69 \%$ in 2030). In the shallow ecotourism scenario there was a reduction of $13.44 \%$ (from $95.0 \%$ in 2020 to $82.23 \%$ in 2030); while in the mass tourism scenario there was a reduction of $41.11 \%$ (from $95.0 \%$ in 2020 to $53.89 \%$ in 2030). This condition shows that the deep ecotourism scenario is the best alternative to maintain biodiversity. Biodiversity is a source of inspiration and recreation, maintaining the availability of water, producing oxygen, maintaining climate stability, as a source of food, and a source of genetic material that is very important for agriculture and industry (Slootweg, 2005). Throughout the history of civilization, humans have over exploited the nature (including biodiversity). To avoid the threat of mass extinctions, one important strategy is to limit human behavior so that it remains within the tolerance limits of the earth's ecosystems (Raven \& Wackernagel, 2020).

The decrease of swamp water reserves during the 10-year simulation is shown in Figure 7(b). In the deep ecotourism scenario, there is a relatively small decrease in swamp water reserves $(0,0001 \%)$ (from 500 million $\mathrm{m}^{3}$ in 2020 to 499.9 million $\mathrm{m}^{3}$ in 2030). In the shallow ecotourism scenario there is a decrease of $19.5 \%$ (from 500 million $\mathrm{m}^{3}$ in 2020 to 402.7 million $\mathrm{m}^{3}$ in 2030); while in the mass tourism scenario there was a decrease of $62.1 \%$ (from 500 million $\mathrm{m}^{3}$ in 2020 to 189.4 million $\mathrm{m}^{3}$ in 2030). This condition shows that the deep ecotourism scenario is the best alternative to maintain swamp water reserves. Rawa Danau FSF must be maintained so as not to be converted into agricultural land, settlements or other uses. The research of Peter et al. (2018) shows that forest land conversion has very serious implications on the ability of forests to maintain water resources. Water 
availability is a crucial factor because billions of people worldwide currently live in water insecurity conditions (Stoler et al., 2020). To get clean water, people have to pay a high price, even disproportionately compared to household income.

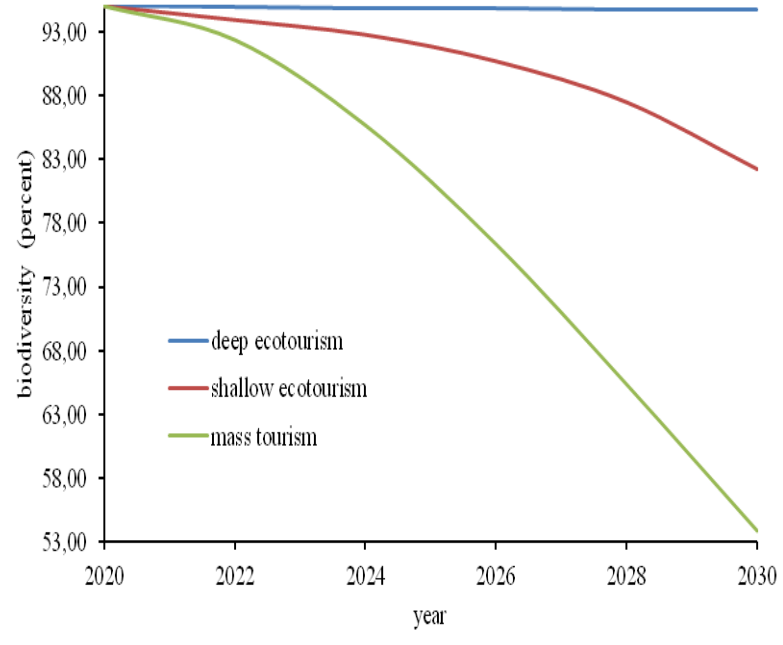

(a)

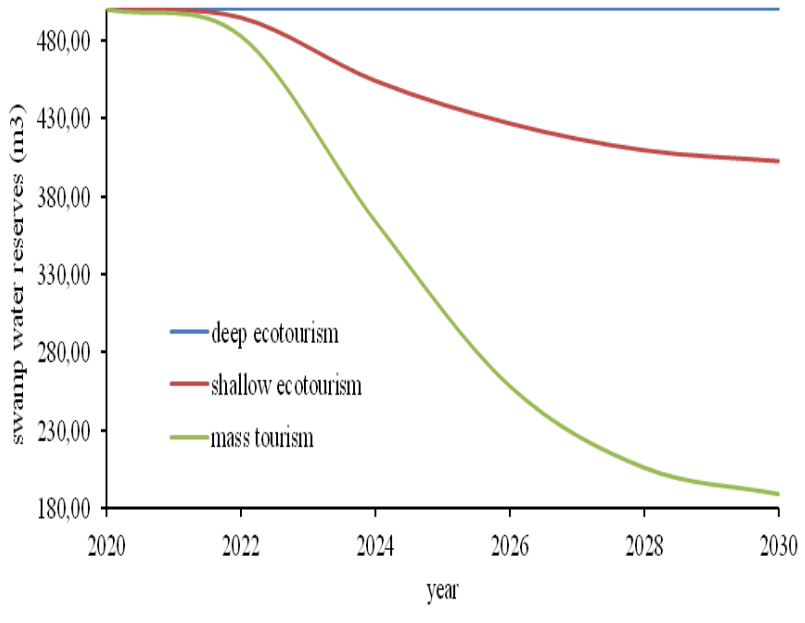

(b)

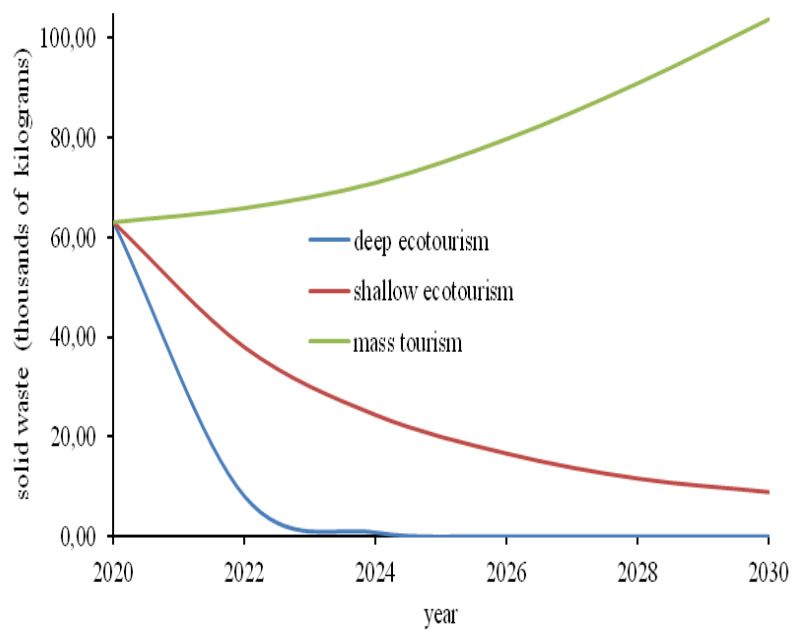

(c)

Fig. 7. Growth patterns of biodiversity (a), swamp water reserves (b), and volume of solid waste (c) according to 3 scenarios of ecotourism management

The decrease in the volume of solid waste during the 10-year simulation is shown in Figure $7(\mathrm{c})$. In the deep ecotourism scenario, there is a significant decrease in the volume of solid waste (99.9\%) (from 62,986 kilograms in 2020 to 0.08 kilograms in 2030). In the shallow ecotourism scenario, there was a decrease of $85.8 \%$ (from 62,986 kilograms in 2020 to 8,926.47 kilograms in 2030). In the mass tourism scenario, the volume of solid waste actually increased by 64.6\% (from 62,986 kilograms in 2020 to 103,682.72 kilograms in 2030). This condition shows that the deep ecotourism scenario is the best alternative to reduce the volume of solid waste. Mismanagement of solid waste has a negative impact on the environment and health, reducing productivity and economic growth (Serge Kubanza \& Simatele, 2020). For this reason, solid waste management must be carried 


\section{ENTREPRENEURSHIP AND SUSTAINABILITY ISSUES}

ISSN 2345-0282 (online) http://jssidoi.org/jesi/ 2020 Volume 8 Number 2 (December) http://doi.org/10.9770/jesi.2020.8.2(4)

out effectively and institutionalized by involving the government, private sector and community participation. Effective management of solid waste will involve all of these components with several principles: 1) understanding of the factors driving the emergence of solid waste, 2) the seriousness of stakeholders in preventing and reducing solid waste, 3 ) understanding the determinants of successful management (Filimonau \& Tochukwu, 2020).

\subsection{Model Validation}

The ability of the model to describe the real state can be determined through model validation. In this study the construction validity test is used, aiming to show that the structure of the model being constructed is logical. The simulation shows that the number of tourists in the mass tourism scenario increases exponentially (Fig.5a). Its orientation on very weak sustainability causes this scenario to be able to increase the volume of solid waste rapidly (Fig.7c), significantly reduced biodiversity (Fig.7a), and drastically reduce swamp water reserves (Fig.7b). The mass tourism scenario also significantly reduces local community income (Fig. 6a), also drastically decreased environmental investment (Fig. 6b). The illustration above shows that the simulation of the model has followed the logical thinking pattern of mass tourism and relevant to the basics of systems archetype (Kim and Anderson, 1998). The simulation also shows that for 10 years, the number of tourists in the deep ecotourism scenario only increased slightly (Fig.5a). Its orientation to very strong sustainability causes this scenario to reduce the volume of solid waste rapidly (Fig.7c), maintain biodiversity (Fig.7a) and swamp water reserves (Fig.7b). The deep ecotourism scenario can also increase local community income (Fig. 6a) and environmental investment (Fig. 6b). The simulation in this scenario is considered in line with the sustainable management policy of the Rawa Danau as an ecotourism destination in Indonesia.

\section{Conclusions}

Considering the various negative impacts of mass tourism, the development of environmentally friendly tourism is now an alternative. That is why people give great expectations to ecotourism, a concept of tourism that integrates economic, social, and ecological conservation interests. As a tropical lowland swamp forest that still remains in Java, the existence of Rawa Danau as an ecotourism destination is important to be explored, because its utilization has not followed the principles of sustainable management. Various problems arise as an impact of mismanagement, e.g.: decrease in forest area due to land conversion, decreased water storage capacity, low local people's income, and empowerment of local communities who do not reach the target. For this reason, a dynamic modeling is then made that integrates various factors in the biophysical, social, and economic dimensions to obtain the best alternative management of ecotourism destinations in the future. Management alternatives are designed in three scenarios: deep ecotourism oriented to very strong/strong sustainability, shallow ecotourism oriented to weak sustainability, and mass tourism oriented to very weak sustainability. System dynamics is used as a method in this study because of its ability to: 1) explore the long-term ecotourism development policies, 2) provide answers to the 'what-if' questions through feedback loops that are built between variables in the system. The results show that deep ecotourism is the most suitable scenario to be implemented in the sustainable management of Rawa Danau as an ecotourism destination in Indonesia. Through this scenario, the control of several parameters that were successfully carried out during the 10 years of simulation are as follows: 1) restrain the growth rate of tourist numbers, the number increased by only $38.4 \%$ (from 12,584 people in 2020 to 17,411 people in 2030). This condition is considered as a fairly logical growth because it is not too high so it does not burden the environment, 2) reforesting almost all converted forest land (97.2\%) (from 8.57 hectares in 2020 remaining 0.24 hectare in 2030). This condition shows that through this scenario the restoration of forest function is going well, 3) local community income increased by $28.6 \%$ (from Rp. 3,500,000 in 2020 to Rp. 4,500,522 in 2030). This condition shows that through this scenario the local community gets adequate economic benefits from ecotourism activities, 4) environmental investment increased by $2,745 \%$ (from $0.2 \%$ in 2020 to $5.69 \%$ in 2030). This condition shows that stakeholders are able to obtain benefits economically, ecologically, and socially 


\section{ENTREPRENEURSHIP AND SUSTAINABILITY ISSUES}

ISSN 2345-0282 (online) http://jssidoi.org/jesi/ 2020 Volume 8 Number 2 (December) http://doi.org/10.9770/jesi.2020.8.2(4)

in an integrated manner, 5) biodiversity reduction is relatively small $(0.33 \%)$ (from $95.0 \%$ in 2020 to $94.69 \%$ in 2030). This condition shows that through this scenario biodiversity can be maintained well, 6) the decrease in swamp water reserves is relatively small (0.0001\%) (from 500 million $\mathrm{m}^{3}$ in 2020 to 499.9 million $^{3}$ in 2030). This condition shows that through this scenario swamp water reserves can be maintained properly, 7) a significant decrease in the volume of solid waste (99.9\%) (from 62,986 kilograms in 2020 to 0.08 kilograms in 2030). This condition shows that this scenario is able to reduce the rate of increase in solid waste volume so that it does not burden the environment.

\section{References}

Acott, T. G., La Trobe, H. L. L., \& Howard, S. H. (1998). An evaluation of deep ecotourism and shallow ecotourism. Journal of Sustainable Tourism, 6(3), 238-253. https://doi.org/10.1080/09669589808667314

Addinsall, C., Scherrer, P., Weiler, B., \& Glencross, K. (2017). An ecologically and socially inclusive model of agritourism to support smallholder livelihoods in the South Pacific. Asia Pacific Journal of Tourism Research, 22(3), 301-315. https://doi.org/10.1080/10941665.2016.1250793

Akis, A. (2011). The effects of mass tourism: A case study from Manavgat (Antalya - Turkey). Procedia - Social and Behavioral Sciences, 19, 289-296. https://doi.org/10.1016/j.sbspro.2011.05.134

Aliani, H., Kafaky, S. B., Monavari, S. M., \& Dourani, K. (2018). Modeling and prediction of future ecotourism conditions applying system dynamics. Environmental Monitoring and Assessment, 190(12). https://doi.org/10.1007/s10661-018-7078-4

Alipour, H., \& Arefipour, T. (2020). Rethinking potentials of Co-management for sustainable common pool resources (CPR) and tourism: The case of a Mediterranean island. Ocean and Coastal Management, 183(April), 104993. https://doi.org/10.1016/j.ocecoaman.2019.104993

Anup, K. C., Rijal, K., \& Sapkota, R. P. (2015). Role of ecotourism in environmental conservation and socioeconomic development in Annapurna conservation area, Nepal. International Journal of Sustainable Development and World Ecology, 22(3), 251-258. https://doi.org/10.1080/13504509.2015.1005721

Baustian, M. M., Clark, F. R., Jerabek, A. S., Wang, Y., Bienn, H. C., \& White, E. D. (2018). Modeling current and future freshwater in flow needs of a subtropical estuary to manage and maintain forested wetland ecological conditions. Ecological Indicators, 85(October 2017), 791-807. https://doi.org/10.1016/j.ecolind.2017.10.005

Bagur-Femenías, L., Perramon, J., \& Amat, O. (2015). Impact of quality and environmental investment on business competitiveness and profitability in small service business: the case of travel agencies. Total Quality Management and Business Excellence, 26(7-8), 840-853. https://doi.org/10.1080/14783363.2014.895523

Biggsa, D., Turpieb, J., Fabriciusc, C., \& Spenceleyd, A. (2011). The value of avitourism for conservation and job creation - An analysis from South Africa. Conservation and Society, 9(1), 80-90. https://doi.org/10.4103/0972-4923.79198

Brandt, J. S., \& Buckley, R. C. (2018). A global systematic review of empirical evidence of ecotourism impacts on forests in biodiversity hotspots. Current Opinion in Environmental Sustainability, 32, 112-118. https://doi.org/10.1016/j.cosust.2018.04.004

Cavallaro, F., Galati, O. I., \& Nocera, S. (2017). Policy Strategies for the Mitigation of GHG Emissions caused by the Mass-Tourism Mobility in Coastal Areas. Transportation Research Procedia, 27, 317-324. https://doi.org/10.1016/j.trpro.2017.12.062

Cesar, A., Pinha, H., \& Sagawa, J. K. (2020). A system dynamics modelling approach for municipal solid waste management and financial analysis. Journal of Cleaner Production, 122350. https://doi.org/10.1016/j.jclepro.2020.122350

Chong, K. L. (2020). The side effects of mass tourism: the voices of Bali islanders. Asia Pacific Journal of Tourism Research, 25(2), 157169. https://doi.org/10.1080/10941665.2019.1683591

Cianga, N. (2017). the Impact of Tourism Activities. a Point of View. Risks and Catastrophes Journal, 20(1/2017), 25-40. https://doi.org/10.24193/rcj2017_02 


\section{ENTREPRENEURSHIP AND SUSTAINABILITY ISSUES}

ISSN 2345-0282 (online) http://jssidoi.org/jesi/ 2020 Volume 8 Number 2 (December) http://doi.org/10.9770/jesi.2020.8.2(4)

Cisneros-Montemayor, A. M., Becerril-García, E. E., Berdeja-Zavala, O., \& Ayala-Bocos, A. (2019). Shark ecotourism in Mexico: Scientific research, conservation, and contribution to a Blue Economy. In Advances in Marine Biology (1st ed.). Elsevier Ltd. https://doi.org/10.1016/bs.amb.2019.08.003

Cobbinah, P. B. (2015). Contextualising the meaning of ecotourism. Tourism Management Perspectives, 16, $179-189$. https://doi.org/10.1016/j.tmp.2015.07.015

D’Cruze, N., Machado, F. C., Matthews, N., Balaskas, M., Carder, G., Richardson, V., \& Vieto, R. (2017). A review of wildlife ecotourism in Manaus, Brazil. Nature Conservation, 22, 1-16. https://doi.org/10.3897/natureconservation.22.17369

Daneshzand, F., Amin-naseri, M. R., Asali, M., Elkamel, A., \& Fowler, M. (2019). A system dynamics model for optimal allocation of natural gas to various demand sectors. Computers and Chemical Engineering, 128, 88-105. https://doi.org/10.1016/j.compchemeng.2019.05.040

Das, M., \& Chatterjee, B. (2015). Ecotourism: A panacea or a predicament? Tourism Management Perspectives, 14, 3-16. https://doi.org/10.1016/j.tmp.2015.01.002

Diaz-Farina, E., Díaz-Hernández, J. J., \& Padrón-Fumero, N. (2020). The contribution of tourism to municipal solid waste generation: A mixed demand-supply approach on the island of Tenerife. Waste Management, 102, 587-597. https://doi.org/10.1016/j.wasman.2019.11.023

Drdácký, M., \& Drdácký, T. (2010). Risks generated by tourism in an environment with cultural heritage assets. International Preservation News: A Newsletter of the IFLA Core Activity on Preservation and Conservation; Tourism and Preservation: Some Challenges, 52(52), 12-17.

Dwomoh, F. K., Wimberly, M. C., Cochrane, M. A., \& Numata, I. (2019). Forest degradation promotes fire during drought in moist tropical forests of Ghana. Forest Ecology and Management, 440(March), 158-168. https://doi.org/10.1016/j.foreco.2019.03.014

e-Review of Tourism Research (eRTR), Vol. 17, No. 4, 2019 http://ertr.tamu.edu. (2019). 17(4), 633-643.

El-Sefy, M., Ezzeldin, M., El-Dakhakhni, W., Wiebe, L., \& Nagasaki, S. (2019). System dynamics simulation of the thermal dynamic processes in nuclear power plants. Nuclear Engineering and Technology, 51(6), 1540-1553. https://doi.org/10.1016/j.net.2019.04.017

Fantinato, E. (2019). The impact of (mass)tourism on coastal dune pollination networks. Biological Conservation, 236(May), 70-78. https://doi.org/10.1016/j.biocon.2019.05.037

Filimonau, V., \& Tochukwu, C. O. (2020). Exploring managerial approaches to mitigating solid waste in hotels of Lagos, Nigeria. Journal of Cleaner Production, 122410. https://doi.org/10.1016/j.jclepro.2020.122410

Gabarda-Mallorquí, A., Garcia, X., \& Ribas, A. (2017). Mass tourism and water efficiency in the hotel industry: A case study. International Journal of Hospitality Management, 61, 82-93. https://doi.org/10.1016/j.ijhm.2016.11.006

Gallagher, A. J., \& Hammerschlag, N. (2011). Global shark currency: The distribution frequency and economic value of shark ecotourism. Current Issues in Tourism, 14(8), 797-812. https://doi.org/10.1080/13683500.2011.585227

Garau-Vadell, J. B., Gutierrez-Taño, D., \& Diaz-Armas, R. (2018). Economic crisis and residents' perception of the impacts of tourism in mass tourism destinations. Journal of Destination Marketing and Management, 7, 68-75. https://doi.org/10.1016/j.jdmm.2016.08.008

Harrison, M. E. (2013). Using conceptual models to understand ecosystem function and impacts of human activities in tropical peat-swamp forests. Wetlands, 33(2), 257-267. https://doi.org/10.1007/s13157-013-0378-0

He, Y., Huang, P., \& Xu, H. (2018). Simulation of a dynamical ecotourism system with low carbon activity: A case from western China. Journal of Environmental Management, 206, 1243-1252. https://doi.org/10.1016/j.jenvman.2017.09.008

Honti, G., Dörgő, G., \& Abonyi, J. (2019). Review and structural analysis of system dynamics models in sustainability science. Journal of Cleaner Production, 240, 118015. https://doi.org/10.1016/j.jclepro.2019.118015

Howe, P. (2019). The triple nexus: A potential approach to supporting the achievement of the Sustainable Development Goals? World Development, 124, 104629. https://doi.org/10.1016/j.worlddev.2019.104629 


\section{ENTREPRENEURSHIP AND SUSTAINABILITY ISSUES}

ISSN 2345-0282 (online) http://jssidoi.org/jesi/ 2020 Volume 8 Number 2 (December) http://doi.org/10.9770/jesi.2020.8.2(4)

Hsu, P. hsiang. (2019). Economic impact of wetland ecotourism: An empirical study of Taiwan's Cigu Lagoon area. Tourism Management Perspectives, 29(April 2018), 31-40. https://doi.org/10.1016/j.tmp.2018.10.003

Igu, N. I., \& Marchant, R. (2016). Aboveground carbon storage in a freshwater swamp forest ecosystem in the Niger Delta. Carbon Management, 7(3-4), 137-148. https://doi.org/10.1080/17583004.2016.1165355

Igu, N. I., \& Marchant, R. (2017). Freshwater swamp forest use in the Niger Delta: Perception and insights. Journal of Forest Research, 22(1), 44-52. https://doi.org/10.1080/13416979.2017.1280887

Ike, M., Donovan, J. D., Topple, C., \& Masli, E. K. (2019). The process of selecting and prioritising corporate sustainability issues: Insights for achieving the Sustainable Development Goals. Journal of Cleaner Production, $236,117661$. https://doi.org/10.1016/j.jclepro.2019.117661

Jamaliah, M. M., \& Powell, R. B. (2018). Ecotourism resilience to climate change in Dana Biosphere Reserve, Jordan. Journal of Sustainable Tourism, 26(4), 519-536. https://doi.org/10.1080/09669582.2017.1360893

Jere Jakulin, T. (2017). Systems Approach to Tourism: A Methodology for Defining Complex Tourism System. Organizacija, 50(3), 208215. https://doi.org/10.1515/orga-2017-0015

Jin-Fang, T., Chao, P., Rui, X., Xiao-Tong, Y., Chen, W., Xu-Zhao, J., \& Yu-Li, S. (2020). Corporate innovation and environmental investment: The moderating role of institutional environment. Advances in Climate Change Research. https://doi.org/10.1016/j.accre.2020.05.003

Kim, D. H., and Anderson, V. (1998), Systems archetype basics. From story to structure, Pegasus, Communications, Inc. Waltham.

Liu, T. M., \& Leung, K. K. (2019). Volunteer tourism, endangered species conservation, and aboriginal culture shock. Biodiversity and Conservation, 28(1), 115-129. https://doi.org/10.1007/s10531-018-1639-2

Lu, X., Yao, S., Fu, G., Lv, X., \& Mao, Y. (2019). Dynamic simulation test of a model of ecological system security for a coastal tourist city. Journal of Destination Marketing and Management, 13(May), 73-82. https://doi.org/10.1016/j.jdmm.2019.05.004

Luna-Reyes, L. F., \& Andersen, D. L. (2003). Collecting and analyzing qualitative data for system dynamics: Methods and models. System Dynamics Review, 19(4), 271-296. https://doi.org/10.1002/sdr.280

Ma, B., Yin, R., Zheng, J., Wen, Y., \& Hou, Y. (2019). Estimating the social and ecological impact of community-based ecotourism in giant panda habitats. Journal of Environmental Management, 250(February), 109506. https://doi.org/10.1016/j.jenvman.2019.109506

Moeis, A. O., Desriani, F., Destyanto, A. R., Zagloel, T. Y., Hidayatno, A., \& Sutrisno, A. (2020). Sustainability Assessment of the Tanjung Priok Port Cluster. International Journal of Technology, 11(2), 353. https://doi.org/10.14716/ijtech.v11i2.3894

Mori, A. S., Lertzman, K. P., \& Gustafsson, L. (2017). Biodiversity and ecosystem services in forest ecosystems: a research agenda for applied forest ecology. Journal of Applied Ecology, 54(1), 12-27. https://doi.org/10.1111/1365-2664.12669

Omagor, N. (1999). Swamp forest plant resources in Uganda: Their uses and conservation challenges. Forests Trees and Livelihoods, 10(2), 107-120. https://doi.org/10.1080/01435698.1999.9752998

Papageorgiou, A. N., \& Lytras, P. N. (2015). The efficacy of alternative tourism development to overcome current crisis: An exploration of the views of the stakeholders of the prefecture of korinthia. Tourismos, 10(2), 97-107.

Peter, A., Mujuru, M., \& Dube, T. (2018). An assessment of land cover changes in a protected nature reserve and possible implications on water resources, South Africa. Physics and Chemistry of the Earth, 107, 86-91. https://doi.org/10.1016/j.pce.2018.09.005

Pizzitutti, F., Walsh, S. J., Rindfuss, R. R., Gunter, R., Quiroga, D., Tippett, R., \& Mena, C. F. (2017). Scenario planning for tourism management: a participatory and system dynamics model applied to the Galapagos Islands of Ecuador. Journal of Sustainable Tourism, 25(8), 1117-1137. https://doi.org/10.1080/09669582.2016.1257011

Priyanto, B., \& Titiresmi, T. (2006). Beberapa Aspek Rawa Danau Sebagai Sumber Air Baku. J. Tek. Ling, 7(3), $277-283$.

Rasouli-Sadaghiani, M. H., Barin, M., Siavash Moghaddam, S., Damalas, C. A., \& Ghodrat, K. (2018). Soil quality of an Iranian forest 


\section{ENTREPRENEURSHIP AND SUSTAINABILITY ISSUES}

ISSN 2345-0282 (online) http://jssidoi.org/jesi/ 2020 Volume 8 Number 2 (December) http://doi.org/10.9770/jesi.2020.8.2(4)

ecosystem after conversion to various types of land use. Environmental Monitoring and Assessment, 190(8). https://doi.org/10.1007/s10661-018-6815-z

Raven, P., \& Wackernagel, M. (2020). Maintaining biodiversity will define our long-term success. Plant Diversity. https://doi.org/10.1016/j.pld.2020.06.002

Saavedra M., M. R., Cristiano, C. H., \& Francisco, F. G. (2018). Sustainable and renewable energy supply chain: A system dynamics overview. Renewable and Sustainable Energy Reviews, 82(March 2017), 247-259. https://doi.org/10.1016/j.rser.2017.09.033

Scheyvens, R., \& Scheyvens, R. (2015). Ecotourism and the Empowerment of Local Communities Ecotourism and the empowerment of local communities. Tourism Management, 20(APRIL 1999), 245-249. https://doi.org/10.1016/S0261-5177(98)00069-7

Secundo, G., Ndou, V., Vecchio, P. Del, \& De Pascale, G. (2020). Sustainable development, intellectual capital and technology policies: A structured literature review and future research agenda. Technological Forecasting and Social Change, 153(March 2019 ), 119917. https://doi.org/10.1016/j.techfore.2020.119917

Serge Kubanza, N., \& Simatele, M. D. (2020). Sustainable solid waste management in developing countries: a study of institutional strengthening for solid waste management in Johannesburg, South Africa. Journal of Environmental Planning and Management, 63(2), 175-188. https://doi.org/10.1080/09640568.2019.1576510

Siakwah, P., Musavengane, R., \& Leonard, L. (2019). Tourism Governance and Attainment of the Sustainable Development Goals in Africa. Tourism Planning and Development, O(0), 1-29. https://doi.org/10.1080/21568316.2019.1600160

Sjaifuddin, S. (2018). Environmental management prospects of industrial area: a case study on Mcie, Indonesia. Business: Theory and Practice, 19, 208-216. https://doi.org/10.3846/btp.2018.21

Sjaifuddin, S., Hidayat, S., Fathurrohman, M., Ardie, R., El Islami, R.A.Z. (2019). The development of food security behavior model through environmental-based learning: a system dynamics approach. Jurnal Pendidikan IPA Indonesia, 8(2), 230-240, https://doi.org/10.15294/jpii.v8i2.18861.

Sjaifuddin, S. (2020). Environmental management of industrial estate based on eco-industrial parks: A system dynamics modeling. Industrial Engineering and Management Systems, 19(1), 211-227. https://doi.org/10.7232/iems.2020.19.1.211

Slootweg, R. (2005). Biodiversity assessment framework: Making biodiversity part of corporate social responsibility. Impact Assessment and Project Appraisal, 23(1), 37-46. https://doi.org/10.3152/147154605781765742

Southgate, C. R. J. (2006). Ecotourism in Kenya: The vulnerability of communities. Journal of Ecotourism, 5(1-2), 80-96. https://doi.org/10.1080/14724040608668448

Stoler, J., Pearson, A. L., Staddon, C., Wutich, A., Mack, E., Brewis, A., Rosinger, A. Y., Adams, E., Ahmed, J. F., Alexander, M., Balogun, M., Boivin, M., Carrillo, G., Chapman, K., Cole, S., Collins, S. M., Escobar-Vargas, J., Freeman, M., Asiki, G., ... Zinab, H. (2020). Cash water expenditures are associated with household water insecurity, food insecurity, and perceived stress in study sites across 20 low- and middle-income countries. Science of the Total Environment, 716(November), 135881. https://doi.org/10.1016/j.scitotenv.2019.135881

Sukholthaman, P., \& Sharp, A. (2016). A system dynamics model to evaluate effects of source separation of municipal solid waste management: A case of Bangkok, Thailand. Waste Management, 52, 50-61. https://doi.org/10.1016/j.wasman.2016.03.026

Sun, Y., Wendi, D., Eon, D., \& Liong, S. (2016). Development and Application of an Integrated Hydrological Model for Singapore Freshwater Swamp Forest. Procedia Engineering, 154, 1002-1009. https://doi.org/10.1016/j.proeng.2016.07.589

Suwarno, A., van Noordwijk, M., Weikard, H. P., \& Suyamto, D. (2018). Indonesia's forest conversion moratorium assessed with an agentbased model of Land-Use Change and Ecosystem Services (LUCES). Mitigation and Adaptation Strategies for Global Change, 23(2), 211229. https://doi.org/10.1007/s11027-016-9721-0

Tan, W. J., Yang, C. F., Château, P. A., Lee, M. T., \& Chang, Y. C. (2018). Integrated coastal-zone management for sustainable tourism using a decision support system based on system dynamics: A case study of Cijin, Kaohsiung, Taiwan. Ocean and Coastal Management, 153(December 2017), 131-139. https://doi.org/10.1016/j.ocecoaman.2017.12.012

Teng, J., Xu, C., Wang, W., \& Wu, X. (2018). A system dynamics - based decision - making tool and strategy optimization simulation of green building development in China. 1259-1270. 


\section{ENTREPRENEURSHIP AND SUSTAINABILITY ISSUES}

ISSN 2345-0282 (online) http://jssidoi.org/jesi/ 2020 Volume 8 Number 2 (December) http://doi.org/10.9770/jesi.2020.8.2(4)

The International Ecotourism Society (TIES, 2015) Available at https://ecotourism.org/. Accessed 29 February 2020.

Tisdell, C., \& Wilson, C. (2005). Perceived impacts of ecotourism on environmental learning and conservation: Turtle watching as a case study. Environment, Development and Sustainability, 7(3), 291-302. https://doi.org/10.1007/s10668-004-7619-6

Torabi, Z. A., Rezvani, M. R., \& Badri, S. A. (2019). Pro-poor tourism in Iran: the case of three selected villages in Shahrud. Anatolia, 30(3), 368-378. https://doi.org/10.1080/13032917.2019.1595689

United Nations World Tourism Organization (UNWTO), 2020. World Tourism Barometer, 18(1). Available at https://webunwto.s3.euwest-1.amazonaws.com/s3fs-public/2020-01/UNWTO_Barom20_01_January_excerpt_0.pdf . Accessed 31 January 2020.

van Der Kaars, S., Penny, D., Tibby, J., Fluin, J., Dam, R. A. C., \& Suparan, P. (2001). Late quaternary palaeoecology, palynology and palaeolimnology of a tropical lowland swamp: Rawa Danau, West-Java, Indonesia. Palaeogeography, Palaeoclimatology, Palaeoecology, 171(3-4), 185-212. https://doi.org/10.1016/S0031-0182(01)00245-0

van der Waal, J. W. H., \& Thijssens, T. (2020). Corporate involvement in Sustainable Development Goals: Exploring the territory. Journal of Cleaner Production, 252, 119625. https://doi.org/10.1016/j.jclepro.2019.119625

Walrave, B., \& Raven, R. (2016). Modelling the dynamics of technological innovation systems. Research Policy, 45(9), 1833-1844. https://doi.org/10.1016/j.respol.2016.05.011

Wit, M. De, Heun, M., \& Crookes, D. (2018). An overview of salient factors, relationships and values to support integrated energyeconomic system dynamics modelling. 29(4), 27-36.

Wondirad, A., Tolkach, D., \& King, B. (2020). Stakeholder collaboration as a major factor for sustainable ecotourism development in developing countries. Tourism Management, 78(October 2019), 104024. https://doi.org/10.1016/j.tourman.2019.104024

World Travel \& Tourism Council (WTTC), 2020. Available at https://www.wttc.org/. Accessed 06 February 2020.

Xu, H., \& Dai, S. (2012). A system dynamics approach to explore sustainable policies for Xidi, the world heritage village. Current Issues in Tourism, 15(5), 441-459. https://doi.org/10.1080/13683500.2011.610499

You, S., Kim, M., Lee, J., \& Chon, J. (2018). Coastal landscape planning for improving the value of ecosystem services in coastal areas: Using system dynamics model. Environmental Pollution, 242, 2040-2050. https://doi.org/10.1016/j.envpol.2018.06.082

Yu, H., Dong, S., \& Li, F. (2019). A System Dynamics Approach to Eco-Industry System Effects and Trends. 28(3), 1469-1482. https://doi.org/10.15244/pjoes/89508

Yu, Y., Shen, W., Yin, Y., Zhang, J., Cai, Z., \& Zhong, W. (2012). Response of soil microbial diversity to land-use conversion of natural forests to plantations in a subtropical mountainous area of southern china. Soil Science and Plant Nutrition, 58(4), 450-461. https://doi.org/10.1080/00380768.2012.708645

Zapata, S., Castaneda, M., Franco, C. J., \& Dyner, I. (2019). Clean and secure power supply: A system dynamics based appraisal. Energy Policy, 131(April), 9-21. https://doi.org/10.1016/j.enpol.2019.04.028

Zorpas, A. A., Voukkali, I., \& Loizia, P. (2015). The impact of tourist sector in the waste management plans. Desalination and Water Treatment, 56(5), 1141-1149. https://doi.org/10.1080/19443994.2014.934721

\section{Acknowledgements}

The author would like to thank Universitas Sultan Ageng Tirtayasa, Indonesia for funding this research 
Sjaifuddin SJAIFUDDIN is an Associate Professor of Environmental Science at the Department of Science Education, Universitas Sultan Ageng Tirtayasa, Serang Banten, Indonesia. His current research focuses on the environmental policy and management.

ORCID ID: 0000-0003-4493-5003

Make your research more visible, join the Twitter account of ENTREPRENEURSHIP AND SUSTAINABILITY ISSUES:

@Entrepr69728810

Copyright (C) 2020 by author(s) and VsI Entrepreneurship and Sustainability Center

This work is licensed under the Creative Commons Attribution International License (CC BY).

http://creativecommons.org/licenses/by/4.0/

(c) (i) Open Access 